\title{
EDUKASI BAHAYA BAHAN KIMIA OBAT YANG TERDAPAT DIDALAM OBAT TRADISIONAL
}

\author{
Wahyu Margi Sidoretno ${ }^{1, *}$, Ira Oktaviani Rz ${ }^{1}$ \\ ${ }^{1}$ Prodi D III Analis Farmasi dan Makanan, Universitas Abdurrab \\ *Email: wahyu.margi@univrab.ac.id
}

\begin{abstract}
ABSTRAK
Obat Tradisional (OT), merupakan campuran bahan-bahan alami yang berasal dari tumbuhan, hewan, mineral, dan gelenika atau campuran dari bahan tersebut yang secara turun-temurun telah digunakan untuk pengobatan. OT membutuhkan waktu yang lebih lama untuk memberikan efek kerja dibandingkan obat kimia. Namun sering kali masyarakat menginginkan OT yang berefek "cespleng". Padahal sebaliknya, jika khasiat OT cespleng dalam sekali pakai maka perlu diwaspadai kemungkinan ditambahkan bahan kimia obat (BKO). BKO yang ditambahkan seringkali tidak terukur takarannya, sehingga berpotensi membahayakan kesehatan jika digunakan dalam jangka waktu yang lama dan terus-menerus. Tujuan pengabdian ini adalah untuk memberikan informasi dan motivasi kepada kader posyandu dan PKK untuk memahami bahaya BKO dalam obat tradisional sehingga mampu memberikan penjelasan dan meningkatkan pengetahuan pada masyarakat atas penggunaan obat tradisional sehingga terwujud masyarakat yang sadar obat. Tahap persiapan meliputi audiensi, koordinasi dan pemantapan dengan mitra kemuadian identifikasi peserta kegiatan. Tahap pelaksanaan yaitu kegiatan berupa pemberian materi, diskusi dan memberikan pelatihan bagaimana cara melihat izin edar obat tradisional pada web BPOM. Pada akhir pelaksanaan diadakan evaluasi dan perbaikan. Hasil kegiatan menunjukkan keberhasilan proses yang ditunjukkan dengan kehadiran peserta mencapai $73,3 \%$. Peningkatan pengetahuan sebesar $60 \%$ dan sebanyak $90 \%$ peserta telah memiliki pengetahuan dalam memilih obat tradisional yang aman digunakan.
\end{abstract}

Kata kunci: edukasi, obat tradisional, bahan kimia obat (BKO)

\begin{abstract}
Traditional medicine (TM) is a mixture of natural resources such as plans, animals, minerals, and galenik or the mixture of that material that is used for medication empirically. It is needing some more times for TM to give pharmacological effect compared to synthetic medicine. However, societies often demand the "cespleng" effect of TM. On the other hand, Needing some attention to possibility of synthetic medicine (SM) composition in "cespleng" effect TM products. The SM is often added without following the right dose, so it danger human health after long term and chronic consumption. This society service aimed to inform and motivate the village representatives to understand the dangerous of SM composition in TM, so could increase the knowledge of village society on right usage of TM. The preparation step included the promotion, coordination, partnership consolidation, and audience identification. The realization step was information sharing, discussion, and 'how to see the Food and Drug Association registration number of TM" training. Lastly, the evaluation and improvement was held in the end of program. The program was success that could be seen from the up to $73.3 \%$ of attendance and the increasing of village society test result (60\%) and skill to chose a save TM for usage (90\%).
\end{abstract}

Key words: Education, traditional medicine, synthetic medicine. 


\section{PENDAHULUAN}

Perkembangan obat tradisional telah meningkat seiring dengan slogan back to nature, hal ini dibuktikan oleh semakin banyaknya industri jamu dan farmasi yang memproduksi obat tradisional. Industri tersebut berlomba-lomba memproduksi obat tradisional secara modern menggunakan mesin modern [1]. Obat tradisional menurut Undang-Undang No. 36 tahun 2009 adalah bahan atau ramuan bahan yang berupa bahan tumbuhan, bahan hewan, bahan mineral, sediaan sarian (galenik), atau campuran dari bahan tersebut yang secara turun temurun telah digunakan untuk pengobatan, dan dapat diterapkan sesuai dengan norma yang berlaku dimasyarakat [2].

Penggunaan obat tradisional yang salah adalah saat masyarakat memiliki ekspektasi bahwa obat tradisional dapat menyembuhkan, sehingga penggunaannya meningkat. Bagi masyarakat, obat tradisional yang bagus adalah yang memberikan reaksi cepat terhadap penyakit yang diderita dengan harga yang terjangkau[3]. Obat tradisional membutuhkan waktu yang lebih lama untuk memberikan efek kerja dibandingkan obat kimia. Namun sering kali masyarakat menginginkan obat tradisional yang berefek "cespleng". Padahal sebaliknya, jika khasiat obat tradisional cespleng dalam sekali pakai maka perlu diwaspadai kemungkinan ditambahkan bahan kimia obat (BKO). Obat tradisional kemasan yang diproses secara modern juga sering menimbulkan masalah bagi konsumen. Produsen menambahkan bahan berbahaya atau bahan kimia obat [4]. Walaupun bukan berarti obat tradisional yang diproses oleh industri rumahan terbebas dari hal ini, tetapi memang kasus penambahan BKO lebih banyak terjadi pada obat tradisional yang dikemas secara modern. Oleh karena itu masyarakat harus lebih berhati-hati dalam memilih obat tradisional, termasuk herbal, baik yang dibuat oleh industri rumah tangga atau dikemas secara modern.

BPOM menyiarkan public warning No. HM. 03.03.1.431.11.16.4010 tanggal 22 November 2016 tentang obat tradisional mengandung bahan kimia obat, ditemukan 43 obat tradisional yang mengandung bahan kimia obat. BKO yang terkadung, antara lain; fenilbutason, allopurinol, deksametason, sildenafil sitrat, taladafil, parasetamol, antalgin, glibenklamid, siutramin, proksikam dan masih banyak yang lainnya. Selain itu juga dilaporkan sebanyak 50 obat tradisional dan suplemen kesehatan mengandung bahan kimia obat dan bahan yang dilarang. Berdasarkan siaran pers tersebut, diketahui bahwa obat tradisional yang dicampur dengan bahan kimia obat didominasi oleh jamu penghilang rasa sakit (pegel linu, rematik) dan herbal penambah stamina (obat kuat).

Beberapa penelitian yang telah dilakukan juga diperoleh data bahwa $\mathrm{BKO}$ masih sering ditemukan dalam obat tradisional, seperti penelitian yang dilakukan di Padang pada tahun 2014, masih ditemukan jamu asam urat yang mengadung bahan kimia obat [5]. Penelitian yang dilakukan oleh Latif (2013), terhadap jamu pegal linu yang dijual di Surakarta, masih ditemukan BKO natrium diklofenak dan fenilbutazon, dengan dosis yang tidak dalam dosis terapi [6]. Sedangkan parasetamol juga masih ditemukan di jamu pegal linu di daerah surabaya[7].

Berdasarkan hal tersebut diatas maka perlu dilakukan peningkatan pengetahuan masyarakat dengan memberikan edukasi dalam kegiatan pengabdian. Pengabdian ini dilaksanakan di Desa Kumain Kecamatan Tandun Kabupaten Rokan Hulu dalam rangka mewujudkan ketelitian, kepedulian, kesadaran, pemahaman dan meningkatkan pengetahuan dalam menggunakan obat tradisional secara tepat dan benar. Desa kumain merupakan desa transmigrasi yang mayoritas masyarakatnya adalah petani sawit. Sasaran kegiatan adalah kelompok masyarakat dan ibu-ibu PKK dengan melibatkan dosen dan mahasiswa D III Analis Farmasi dan Makanan, Organisasi Profesi dan stake holder terkait lainnya. 
Peserta dari pengabdian ini adalah ibu-ibu kader posyandu dan ibu-ibu PKK, pemilihan ini dikarenakan mereka yang selalu berinteraksi dengan masyarakat secara langsung. Masyarakat desa kumain adalah petani kelapa sawit yang kesehariannya mengurus kebun. Penduduknya terdiri dari 667 KK (kepala keluarga) mayoritas berasal dari jawa karena mengikuti program pemerintah (transmigrasi) memungkinkan mereka untuk lebih memilih obat tradisional sebagai pilihan dalam mempertahankan kesehatannya dan kebugaran tubuhnya. Obat tradisional dipilih selain harganya yang relatif terjangkau juga kesediaanya lebih mudah untuk di peroleh di kawasan tersebut.

Permasalahan yang timbul adalah kurangnya pengetahuan masyarakat tentang obat tradisional yang mengandung bahan kimia obat. BPOM memperingatkan masyarakat untuk tidak mengonsumsi produk-produk jamu yang mengandung bahan kimia obat. Karena, termasuk dalam kategori zat yang berbahaya bagi tubuh. Bahan kimia obat (BKO), masuk dalam kategori obat keras. Obat keras memiliki dosis atau takaran dalam pemakaiannya. Jika digunakan tanpa memperhatikan dosisnya maka dapat berdampak buruk pada kesehatan. Apabila masyarakat mengkonsumsi obat tradisional atau jamu yang mengandung BKO tersebut, akan mengalami risiko gangguan kesehatan serius, terutama pada lambung, jantung, ginjal, dan hati. Bahkan, bisa berujung pada kematian.

Tujuan pengabdian ini memberikan informasi dan motivasi pada kader posyandu dan PKK untuk memahami bahaya bahan kimia obat dalam obat tradisional sehingga mampu memberikan penjelasan dan meningkatkan pengetahuan pada masyarakat atas penggunaan obat tradisional sehingga terwujud masyarakat yang sadar obat.

\section{TINJAUAN PUSTAKA}

Kesehatan adalah keadaan sehat, baik secara fisik, mental, spiritual maupun sosial yang memungkinkan setiap orang untuk hidup produktif secara sosial dan ekonomi. Maka jika suatu masyarakat sehat maka akan meningkatkan produktifitas dan kesejahteraannya. Menurut Undang-Undang Kesehatan No. 36 tahun 2009, obat tradisional adalah bahan atau ramuan bahan yang berupa bahan tumbuhan, bahan hewan, bahan mineral, sediaan sarian (galenika), atau campuran dari bahan tersebuat yang secara turun temurun telah digunakan untuk pengobatan, dan dapat diterapkan sesuai dengan norma yang berlaku dimasyarakat.

Badan Pengawas Obat dan Makanan mengelompokkan obat tradisional atas jamu, obat herbal terstandar (OHT) dan fitofarmaka. Sesuai dengan Permenkes No. 003/Menkes/Per/I/2010 tentang jamu dalam penelitian berbasis pelayanan kesehatan, jamu adalah obat tradisional Indonesia. Berdasarkan Keputusan Ka. BPOM No HK.00.05.4.2411, 2004, jamu harus memenuhi kriteria; aman sesuai dengan persyaratan yang ditetapkan, klaim khasiat dibuktikan berdasarkan data empiris, dan memenuhi persyaratan mutu yang berlaku. Penandaan penggolongan obat bahan alam di Indonesia dapat dilihat seperti pada gambar berikut ini (Gambar 1).

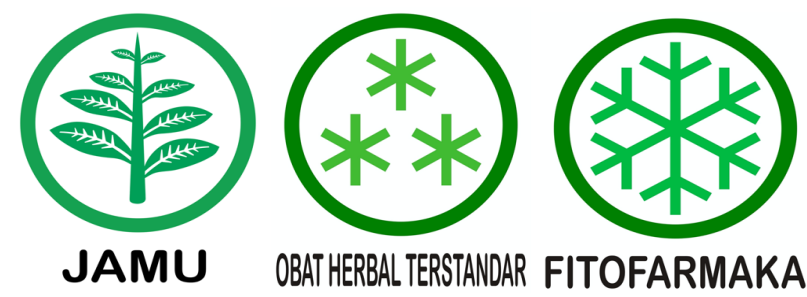

Gambar 1. Penandaan Penggolongan Obat Bahan Alam 
Obat herbal terstandar merupakan obat tradisional yang telah mengalami pembuktian keamanan dan khasiat secara ilmiah melalui uji praklinik dan bahan baku obatnya telah terstandarisasi. Fitofarmaka merupakan obat tradisional yang telah terbukti keamanannya dan khasiatnya secara ilmiah mulai dari proses penelitian praklinik sampai uji klinik pada manusia, bahan baku dan produk jadi telah terstandarisasi. Berdasarkan persyaratan obat tradisional, maka tidak boleh mengandung bahan kimia obat sama sekali. Guna melindungi masyarakat dari peredaran obat tradisional yang tidak memenuhi persyaratan keamanan, khasiat dan mutu, pemerintah mengeluarkan Permenkes nomer 7 tahun 2012, tentang produk obat tradisional yang beredar di wilayah Indonesia wajib, memiliki izin edar dan harus memenuhi kriteria yaitu menggunakan bahan yang memenuhi persyaratan keamanan dan mutu, dibuat dengan menerapkan CPOTB, memenuhi persyaratan Farmakope Herbal Indonesia, berkhasiat secara empiris, turun temurun, dan/atau secara ilmiah, penandaan berisi informasi yang objektif, lengkap dan tidak menyesatkan. Obat tradisional tidak diperbolehkan mengandung bahan kimia obat yang merupakan hasil isolasi atau sintetik berkhasiat obat. Hal ini disebabkan karena terjadi interaksi antara komponen senyawa yang terdapat pada obat tradisional dengan obat sintetik. Beberapa tanaman yang telah teridentifikasi memiliki interaksi dengan obat sintetik adalah Allium sativum, Ginkgo biloba dengan obat-obat antiplatelet seperti aspirin, warfarin dan ibuprofen.

Obat tradisional yang sering teridentifikasi bahan kimia obat adalah obat tradisional yang diindikasikan untuk afrodisiak, penghilang rasa sakit dan rematik Hasil penelitian Sari, 2012 melaporkan bahwa terdapat 9 sampel jamu positif mengandung sildenafil sitrat. Sampel yang digunakan pada penelitian ini sebanyak 27 buah jamu yang memiliki nomer registrasi dan dibeli dari 21 toko jamu yang berada di kecamatan Klojen di kota Malang. Pada kemasan disebutkan bahwa jamu tersebut digunakan untuk jamu kuat lelaki. Metode analisis yang digunakan yaitu Kromatografi Lapis Tipis-Densitometri. Hasil analisis menunjukkan pada 9 sampel memberikan noda dengan nilai rf dan pola spektra yang sama dengan standar sildenafil sitrat. [8]

Hasil penelitian Nurhasnawati, 2014 terhadap sampel jamu asam urat yang beredar di kecamatan Sungai Kunjang Samarinda, di dapatkan hasil yaitu dari tiga sampel, teridentifikasi 1 sampel yang mengandung parasetamol dengan pengujian reaksi warna dan KLT (kromatografi lapis tipis). Pada penelitian Wirastuti, 2016 pemeriksaan terhadap kandungan prednison pada sediaan jamu rematik menggunakan metoda analisis KLTdensitometri dengan fase gerak kloroform:etil asetat (1:9), didapatkan hasil dari 5 sampel yang dilakukan analisis terdapat 1 sampel yang positif mengandung prednison dengan kadar 475,421 $\mu \mathrm{g} / \mathrm{mL}$.[9]

Siaran pers yang dilakukan oleh BPOM pada tanggal 11 desember 2017 (public warning No. B-IN.05.03.1.43.12.17.5966) tentang obat tradisional mengandung bahan kimia obat. Menyatakan bahwa selama periode Desember 2016 sampai November 2017, Badan POM RI menemukan 39 obat tradisional mengandung BKO. BKO yang teridentifikasi dalam produk OT tersebut didominasi oleh sildenafil dan turunannya yang beresesiko dapat menimbulkan efek kehilangan penglihatan dan pendengaran, stroke, serangan jantung, hingga kematian. BKO lainnya yang juga ditemukan adalah pereda nyeri seperti fenilbutazon.

\section{BAHAN DAN METODE}

Bahan-bahan yang diperlukan pada saat kegiatan berlangsung adalah bahan seminar serta bahan pretest dan postest guna mengetahui peningkatan pemahaman tentang bahaya bahan kimia obat yang terkandung dalam obat tradisional. 
Kegiatan pengabdian ini dapat terlaksana dengan beberapa langkah penerapan dan tahapan yang dilakukan oleh tim pelaksana pengabdian, terdiri dari:

Tahap persiapan merupakan tahap yang diperlukan untuk mengumpulkan informasi yang berkaitan dengan khalayak sasaran. Tahap persiapan ini terdiri dari:

1. Pengumpulan data calon peserta pelatihan yang aktif di Kader Posyandu dan PKK

2. Diskusi dengan perangkat desa dan panitia yang di bentuk oleh desa

3. Diskusi dengan anggota tim pelaksana kegiatan pengabdian dan penentuan beban kerja anggota tim

4. Mempersiapkan peralatan serta bahan yang diperlukan dalam kegiatan pengabdian Tahap ini merupakan tahap pelaksanaan kegiatan pengabdian, berupa ceramah, diskusi, ice breaking dan simulasi terkait obat dan obat tradisional, memberikan pelatihan bagaimana cara melihat obat tradisional tersebut terdaftar atau tidak di BPOM dengan melihat secara langsung website BPOM (http://www.pom.go.id). Pada akhir pelaksanaan di adakan evaluasi terhadap peserta untuk mengetahui tingkat pemahaman dari materi yang diberikan. Evaluasi kegiatan dilakukan berdasarka tingkat pengetahuan peserta selama mengikuti acara pengabdian.

a. Pengetahuan awal para peserta terlebih dahulu diobservasi dengan cara melakukan pretest. Soal pretest berkaitan dengan pengetahuan tentang obat tradisional dan potensi buruk yang akan terjadi jika obat tradisional mengandung bahan kimia obat.

b. Pengetahuan akhir para peserta di evaluasi setelah (postest) pemberian materi.

\section{HASIL DAN PEMBAHASAN}

Pengabdian masyarakat merupakan suatu gerakan proses pemberdayaan diri untuk kepentingan masyarakat. Pada pelaksanaan pengabdian masyarakat ini, didapatkan hasil peningkatan pengetahuan dari peserta seminar yang terlihat pada nilai rata-rata pretes yaitu 60 sedangkan postest 90, yaitu menunjukkan peningkatan 50\% dibandingkan dengan pretest. Antusiasme peserta sangat tergambar dengan tidak adanya peserta yang keluar dari ruangan selama sesi pegebdian berlangsung. Selanjutnya tim pengabdi membagikan flyer/brosur tentang bahaya bahan kimia obat dalam obat tradisional dan memberikan spanduk yang di pasang pada posyandu yang ada di desa Kumain.
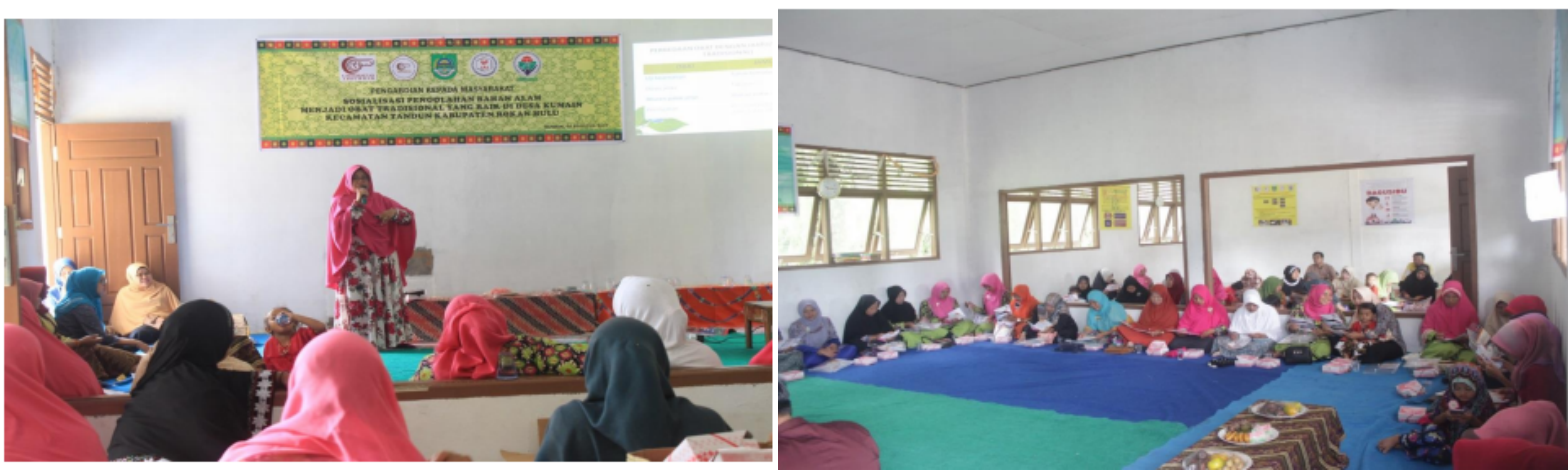

Gambar 2. Pelaksanaan Pemberian Materi dan Peserta Pengabdian

Gambar 2, merupakan sesi pengabdian dengan metoda ceramah oleh pemateri. Peserta mendengarkan, selanjutnya sesi tanya jawab. Dari sesi tanya jawab, diperoleh banyak sekali pertanyaan menyangkut dengan obat tradisional baik cara pakai dan lama pemakaiannya. 
Tetapi tidak lepas dari tema bahaya penggunaan obat tradisional yang mengandung bahan kimia obat.

Bahaya bahan kimia obat yang terdapat pada obat tradisional tidak dapat terlihat secara cepat atau pada saat mengkonsumsinya langsung tetapi dalam jangka waktu yang lama, seperti penggunaan parasetamol (obat penghilang rasa sakit dan penurun panas) yang terus menerus dan pada dosis yang besar dapat enyebabkan kerusakan hati, fenilbutason (obat penghilang rasa sakit/analgesik) dapat menyebabkan pendarahan lambung karena menghambat prostaglandin, deksametason (golongan obat kortikosteroid) jika digunakan tidak sesuai dengan anjuran maka dapat menyebabkan meningkatnya kadar gula darah, pengeroposan tulang, menghambat pertumbuhan anak dan dapat menyebabkan gemuk terutama pada wajah (moon face). Penggunaan jamu kuat yang mengandung sildenafil dan atau taladafil dapat menyebabkan kematian karena efeknya terhadap pembuluh darah [10].

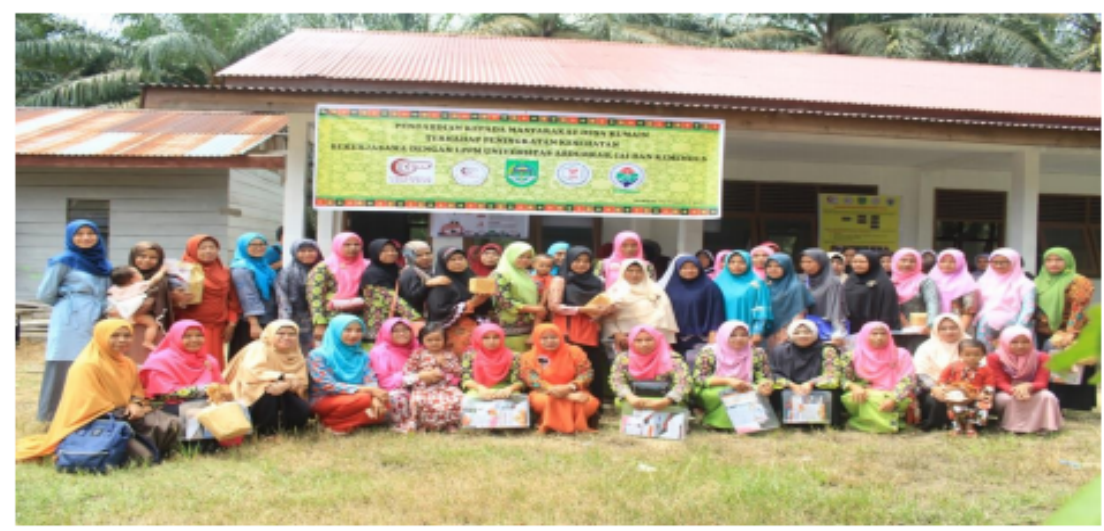

Gambar 3. Foto Bersama Tim Pengabdi dan Peserta pengabdian

Dengan paparan di atas, maka dapat dipahami bahayanya mengkonsumsi obat-obat herbal yang dicampur dengan obat kimia tanpa aturan yang benar. Apalagi masyarakat sering berpendapat bahwa jamu itu aman dan bisa digunakan dalam jangka panjang. Efek obat herbal atau jamu memang pada umumnya terjadi secara bertahap (perlahan). Jika terlalu cepat atau terlalu kuat, justru boleh dicurigai adanya campuran dengan obat kimia. Kami menghimbau masyarakat untuk berhati-hati memilih dan membeli obat herbal. Belilah di apotek atau toko obat yang dipercaya. Pilihlah obat herbal yang diproduksi oleh industri farmasi yang sudah cukup dikenal, mereka biasanya tidak berani bertindak kriminal dengan mencampurkan bahan kimia obat ke dalam produk obat herbalnya. Terakhir peserta dan tim pengabdian masyarakat Program Studi D-III Anafarma (Analis Farmasi dan Makanan) FKIK, Universitas Abdurrab melakukan foto bersama (gambar 3).

\section{KESIMPULAN}

Berdasarkan uraian hasil dan pembahasan maka dapat disimpulkan bahwa pengetahuan peserta pengabdian (kader Posyandu dan ibu-ibu PKK) meningkat sebanyak $50 \%$ dalam mengetahui bahaya bahan kimia obat dalam obat tradisional. Saran yang dapat diberikan pada masyarakat adalah sebaiknya agar lebih hati-hati menggunakan obat tradisional yang beredar, apalagi yang tidak memiliki izin edar.

\section{UCAPAN TERIMA KASIH}

Ucapan terimakasih kami haturkan kepada : Kepala Desa Kumain bersama staff, Ketua penggerak PKK dan Ketua Kader Posyandu yang telah membantu terwujudnya 
kegiatan pengabdian ini. Tidak lupa terimakasih kami kepada Kementrian Pedesaan dan LPPM Universitas Abdurrab yang telah mendanai kegiatan Pengabdian Masyarakat ini.

\section{DAFTAR PUSTAKA}

M. Lestari handayani and m. Suharmiati, cara benar meracik obat tradisional. Agromedia, 2006.

U.-u. Nomor, "tahun 2009 tentang kesehatan," lembaran negara republik indones. Nomor, vol. 144, p. 36, 2009.

S. A. Saputra, "identifikasi bahan kimia obat dalam jamu pegel linu seduh dan kemasan yang dijual di pasar bandar," j. Wiyata, vol. 2, no. 2, pp. 188-192, 2017.

Bpom, "badan pengawas obat dan makanan versi mobile," bpom, 2016. [online]. Available: http://www.pom.go.id/mobile/index.php/view/pers/337/waspada-obat-tradisionalmengandung-bahan-kimia-obat--teliti-sebelum-membeli-dan-mengonsumsi.html. [accessed: 26-nov-2017].

H. P. P. Agus, "analisis bahan kimia obat pada sediaan jamu asam urat yang beredar di kota padang." Universitas andalas, 2014.

A. Lathif, "analisis bahan kimia obat dalam jamu pegal linu yang di jual di surakarta menggunakan metode spektrofotometri uv." Universitas muhammadiyah surakarta, 2013.

T. Tourisma, "identifikasi dan penentuan kadar parasetamol dan fenilbutazon dalam jamu pegal linu yang beredar di surabaya secara kromatografi lapis tipis-densitometri." Widya mandala catholic university surabaya, 2011.

A. Y. U. K. Sari, "analisis kualitatifbahan kimia obat dalam sediaan jamu kuat priadengan metode klt-densitometri yang beredar dikecamatan klojen kota malang." University of muhammadiyah malang, 2012.

A. Wirastuti, a. A. Dahlia, and a. Najib, "pemeriksaan kandungan bahan kimia obat (bko) prednison pada beberapa sediaan jamu rematik," j. Fitofarmaka indones., vol. 3, no. 1, pp. 130-134, 2016.

B. G. Katzung and a. J. Trevor, basic and clinical pharmacology 14e. Mcgraw-hill education, 2017. 